\title{
SCIENTIFIC REPORTS

\section{OPEN A synergic approach for nutrient recovery and biodiesel production by the cultivation of microalga species in the fertilizer plant wastewater}

\author{
Indu Ambat $\mathbb{D}^{1 *}$, Sabina Bec ${ }^{1}$, Elina Peltomaa ${ }^{2,3,4}$, Varsha Srivastava ${ }^{1}$, Anne Ojala ${ }^{2,3,4}$ \& \\ Mika Sillanpää ${ }^{1}$
}

The combination of wastewater treatment and biodiesel production using algal cultivation was studied in the present work. The two main goals of the work were achieved by the cultivation of freshwater microalgae such as Chlamydomonas sp., Scenedesmus ecornis, and Scenedesmus communis in two different dilutions of fertilizer plant wastewater (FWWD1 and FWWD2) collected from Yara Suomi Oy, Finland. The growth pattern of different algal species in FWWD1 and FWWD2 was observed. The effect of $\mathrm{pH}$ on biomass concentration, lipid content, biomass productivity, and lipid productivity by all three algal species in FWWD1 and FWWD2 were monitored. The maximum biomass concentration and productivity were observed in FWWD1 at pH7.5 for Chlamydomonas sp. and at pH 8.5 for S. ecornis and S. communis. The maximum lipid content was detected in Chlamydomonas sp at pH5.5, followed by $S$. ecornis and then S. communis at $\mathrm{pH} 7.5$ in FWWD2 obtained after co-solvent extraction method. The most significant removal percentage of COD by all algal species were observed in FWWD1, whereas the highest removal percentage of TN and TP were detected in FWWD2, respectively. The fatty acid methyl ester (FAME) characterization of each algal species in FWWD1 and FWWD2 at their optimum pH was investigated to determine the quality of obtained biodiesel.

The scarcity of conventional fuels and pollution of water resources have been a global issue with the population growth ${ }^{1,2}$. Thus, it leads to the need for sustainable alternative fuels and reusing of wastewater using different treatment technologies ${ }^{2,3}$. Biodiesel composed of fatty acid methyl esters (FAME) serves as one of the viable alternative fuels. The animal fat, vegetable oil, and algal oil serves as sources for FAME production. The renewability, biodegradability, eco-friendly nature, and non-toxicity are the features possessed by FAME ${ }^{4-7}$.

In 1942, the concept of using algae for energy production was introduced by Harder and Witch. Later in 1955 Meier, and Ostwald and Golueke in 1960 used algal carbohydrates for production of methane $\left(\mathrm{CH}_{4}\right)$ gas under anaerobic conditions. The energy production from algal species attained key impulsion in the early $1970 \mathrm{~s}$ due to the increase in the cost of energ $y^{6,8}$. In current years, the microalgae serve as a potential source for the synthesis of biodiesel and also play a substantial role in the removal of nutrient from wastewater ${ }^{3,6,9-14}$. The algal species possess features such as high growth rate, high oil content, availability, the capability to reduce greenhouse gases (GHGs) in the atmosphere, and besides, algal production does not compete with food market which made them a favorable feedstock for biodiesel production ${ }^{3,15-17}$. In comparison with conventional methods such as chemical precipitation and biological nitrification/denitrification for wastewater treatment process algae offer efficient nutrient removal by the utilization of nutrients in wastewater for its growth and production of biomass

\footnotetext{
${ }^{1}$ Department of Green Chemistry, School of Engineering Science, Lappeenranta University of Technology, Sammonkatu 12, FI-50130, Mikkeli, Finland. 'Faculty of Biological and Environmental Sciences, Ecosystems and Environment Research Programme, University of Helsinki, Niemenkatu 73, FI -15140, Lahti, Finland. ${ }^{3}$ Institute of Atmospheric and Earth System Research (INAR)/Forest Sciences, University of Helsinki, P.O. Box 27, FI-00014, Helsinki, Finland. ${ }^{4} \mathrm{Helsinki}$ Institute of Sustainability Science (HELSUS), Yliopistonkatu 3, 00014, Helsingin, yliopisto, Finland.*email: indu.ambat@lut.fi
} 
for biodiesel production ${ }^{2,6,12,13,18}$. Therefore, biodiesel derived from algal biomass grown in wastewater medium serves as a promising sustainable, eco-friendly, and cost-efficient source of energy $y^{2,12,14,16,19-21}$.

In 2010, Flamos et al. stated that microalgae production has excellent potentials in economic dimensions as it can increase revenues and employment. The co-products and byproducts obtained as a result of biofuel production offer supplementary economic values. Furthermore, the income taxes of all countries can be raised because of microalgae production. Moreover, microalgae production can create openings in developing countries, and also biofuel based businesses can improve the energy security and dependency of different nations on crude oil imports ${ }^{22}$. Later in 2016, Hwang et al. reported that microalgae-based wastewater treatment systems demonstrate an eco-friendly and low-cost wastewater treatment alternative in comparison with conventional wastewater treatment processes ${ }^{23}$.

The biodiesel production from algal biomass includes different steps like algal cultivation, biomass collection, lipid extraction, and transesterification of lipids. The lipid extraction step is of extreme importance in the algal biodiesel production process. The most widely used methods for lipid extraction from algal species are solvent extraction, enzyme extraction, and mechanical extraction ${ }^{2,16,21,24}$. All these methods are energy demanding and also require large quantities of solvents. For commercialization and economical production of algal biodiesel it must be attained with low consumption of energy and solvents. Recently, ionic liquids (ILs) have got more considerable attention because of their thermal stability, non-volatile nature, low vapor pressure, shorter reaction time, specific stability, polarity, and high-performance yield. Hence, ILs act as a potential substitute for volatile solvents and also considered as greener solvents. ILs are salts sustained as a liquid at moderate to room temperature $\left(0-140^{\circ} \mathrm{C}\right)$ and they comprise of a nitrogen-containing ring structure (eg: pyrinidine or imidazolium) as cation to which a wide range of functional side groups can be attached ${ }^{21,25,26}$. In 2010 methanol was stated as right choice as polar covalent molecules (PCM) for lipid extraction by Young et al. and in 2014, 1-ethyl-3-methyl imidazolium diethyl phosphate, [Emim] DEP reported as a best ionic liquid by Choi et al. ${ }^{21,25}$.

The main objective of the present work is the simultaneous removal of nutrients and biodiesel production from wastewater collected from a fertilizer plant using Chlamydomonas sp., Scenedesmus ecornis, and Scenedesmus communis. To the best of our knowledge, the cultivation of these algal species in wastewater for biodiesel production has not been reported. Moreover, the lipid content of algal species used in this study is comparable to other algal species commonly used for biodiesel production and nutrient removal from various kinds of wastewater ${ }^{27}$. The earlier reported studies explored various kinds of wastewater, but fertilizer wastewater was rather scanty and not well explored ${ }^{6}$. Hence the growth of algal species in fertilizer wastewater (FWW) was examined. The nutrient removal efficiency of the algal species in the nitrogen-rich environment was investigated. Based on previously reported studies suggested that ILs and PCM combination showed better results for lipid extraction in a more eco-friendly way than consuming large volatile organic solvents ${ }^{21,24-26}$. Therefore, the extraction of lipids using a novel co-solvent system, [Emim] DEP ionic liquid coupled with PCM as methanol was performed. The influence of $\mathrm{pH}$ on biomass concentration, biomass productivity, lipid content, and lipid productivity of various algal species in fertilizer wastewater (FWW) was observed. The FAME composition and properties of the obtained biodiesel were studied.

\section{Materials and Methods}

Characterization of collected wastewater. The Fertilizer plant wastewater (FWW) was collected from Yara Suomi Oy, Siilinjärvi, Pohjois-Savo, Finland. The physicochemical properties of the collected wastewater sample were analyzed. The parameters of wastewater such as COD, total nitrogen (TN), and total phosphorus (TP) were analyzed according to standard methods (APHA, 2012) and measured with a spectrophotometer DR3900 (Hatch, Germany) ${ }^{28}$. The concentration of metals and the NH4-N, NO3-N in wastewater samples were analyzed using Agilent 5110 inductively coupled plasma (ICP) and using Hach Lange kits (Hach Lange, Germany) and DR 3900 spectrophotometer, respectively ${ }^{1,29-31}$.

Pre-cultivation of algal species. The S. communis, S. ecornis, and Chlamydomonas sp. were given by one of the authors (E. Peltomaa, University of Helsinki, Finland). The Modified WC Medium (MWC) was used to pre-culture and maintain all the algal species. MWC contains the following ingredients: (1) chemicals such as $\mathrm{CaCl}_{2} .2 \mathrm{H}_{2} \mathrm{O}\left(36.80 \mathrm{gL}^{-1}\right), \mathrm{MgSO}_{4} .7 \mathrm{H}_{2} \mathrm{O}\left(37.00 \mathrm{gL}^{-1}\right), \mathrm{NaHCO}_{3}\left(12.60 \mathrm{gL}^{-1}\right), \mathrm{K}_{2} \mathrm{HPO}_{4} .3 \mathrm{H}_{2} \mathrm{O}\left(11.40 \mathrm{gL}^{-1}\right), \mathrm{NaNO}_{3}$ $\left(85.00 \mathrm{~g} \mathrm{~L}^{-1}\right), \mathrm{Na}_{2} \mathrm{O}_{3} \mathrm{Si} .5 \mathrm{H}_{2} \mathrm{O}\left(21.20 \mathrm{gL}^{-1}\right)$; (2) the combined trace elements EDTANa $\left(4.36 \mathrm{gL}^{-1}\right), \mathrm{FeCl}_{3} .6 \mathrm{H}_{2} \mathrm{O}$ $\left(3.15 \mathrm{~g} \mathrm{~L}^{-1}\right), \mathrm{CuSO}_{4} .5 \mathrm{H}_{2} \mathrm{O}\left(0.01 \mathrm{~g} \mathrm{~L}^{-1}\right), \mathrm{ZnSO}_{4} .7 \mathrm{H}_{2} \mathrm{O}\left(0.022 \mathrm{~g} \mathrm{~L}^{-1}\right), \mathrm{CoCl}_{2} \cdot 6 \mathrm{H}_{2} \mathrm{O}\left(0.01 \mathrm{~g} \mathrm{~L}^{-1}\right), \mathrm{MnCl}_{2} .4 \mathrm{H}_{2} \mathrm{O}$ $\left(0.18 \mathrm{~g} \mathrm{~L}^{-1}\right), \mathrm{Na}_{2} \mathrm{MoO}_{4} .2 \mathrm{H}_{2} \mathrm{O}\left(0.006 \mathrm{~g} \mathrm{~L}^{-1}\right), \mathrm{H}_{3} \mathrm{BO}_{3}\left(1 \mathrm{~g} \mathrm{~L}^{-1}\right)$; (3) vitamin mix thiamine HCL $\left(0.1 \mathrm{~g} \mathrm{~L}^{-1}\right)$, biotin $\left(0.0005 \mathrm{~g} \mathrm{~L}^{-1}\right)$, cyanocobalamine $\left(0.0005 \mathrm{gL}^{-1}\right)$; (4) TES buffer $\left(0.115 \mathrm{~g} \mathrm{~L}^{-1}\right)$. Each algal strain was grown in tissue culture flasks with MWC medium as triplicates in a growth cabinet (SANYO growth Chamber MLR-350 H; 294L with white light source) at $20^{\circ} \mathrm{C}$ with a continuous photon flux density (PFD) of $150 \mu \mathrm{mol} \mathrm{m}^{-2} \mathrm{~s}^{-1}$.

Cultivation of algal species in wastewater samples. Initially, due to high nutrient concentrations the fertilizer plant wastewater samples were diluted 100 fold (FWWD1) and 200 fold (FWWD2), respectively. Carbon source $\left(\mathrm{NaHCO}_{3}\right)$ in $250 \mathrm{mgL}^{-1}$ concentration was introduced to each dilution of the wastewater sample for algal growth. The $\mathrm{pH}$ of the samples was adjusted to 7.5 before algal inoculation using sodium hydroxide. Later, the $\mathrm{pH}$ adjusted samples were autoclaved. The effect of $\mathrm{pH}$ on algal biomass production and lipid content were determined by conducting experiments at various $\mathrm{pH}$ such as $5.5,7.5$, and 8.5 correspondingly. The initial inoculum concentration was $0.20 \mathrm{gL}^{-1}, 0.21 \mathrm{gL}^{-1}$, and $0.20 \mathrm{gL}^{-1}$ for Chlamydomonas sp., S. communis, and S. ecornis, respectively. All the three microalgae strains were cultivated as triplicates separately in batch culture flasks with a working volume of $500 \mathrm{ml}$ for ten days at $25^{\circ} \mathrm{C}$ with a continuous PFD of $150 \mu \mathrm{mol} \mathrm{m}^{-2} \mathrm{~s}^{-1}$. 
Analytical methods. Algal growth rate and biomass productivity. The optical density of each algal strain was observed on alternative days at $680 \mathrm{~nm}$ using the spectrophotometric method. The biomass of each strain was collected using centrifugation and followed by freeze-drying (Christ Alpha 2-4 LD plus). Later, the dry weight (DW) measurements of algal samples were performed to confirm the algal growth ${ }^{9-11,14}$. The biomass of each strain at the initial phase, log phase, and late $\log$ phase were determined gravimetrically and biomass productivity calculated as described in Eq. $1^{10,12,14}$.

$$
\text { Biomass productivity }\left(m g L^{-1} d^{-1}\right)=\frac{\text { Biomass concentration }\left(m g L^{-1}\right)}{\text { No. of days }}
$$

Nutrient removal efficiency of algal strains. The $30 \mathrm{ml}$ of sample was collected from each culture separately on alternative days to examine the nutrient removal capability. The collected samples were centrifuged and filtered using $0.45 \mu \mathrm{m}$ PTFE syringe filters from Van Waters and Rogers (VWR) international. The filtered samples were then investigated for TN, COD, and TP according to standard methods (APHA, 2012) and measured with a spectrophotometer DR3900 (Hatch, Germany) ${ }^{28}$. Nutrient removal efficiency of each algal strain was calculated using Eq. 2.

$$
\text { Removal percentage }(\%)=\frac{\text { Initial concentration }- \text { Final concentration }}{\text { Initial concentration }} \times 100
$$

Lipid extraction and lipid productivity. The lipid extraction of algal biomass was achieved with the help of the co-solvent system consisting of 1-ethyl-3-methyl imidazolium diethyl phosphate, [Emim] DEP and PCM (methanol). During the extraction process, $500 \mathrm{mg}$ of dried algal biomass was dispersed in the co-solvent system prepared by mixing [Emim] DEP and methanol in 1.2:1 (v/v) ratio. The biomass-co-solvent system was mixed continuously for $18 \mathrm{~h}$ at $65^{\circ} \mathrm{C}$, and later, it was cooled at room temperature. The addition of hexane results in the extraction of lipids and centrifugation was conducted for the separation of ionic liquid- PCM phase and lipid-containing hexane phase. The hexane was removed by rotary evaporator for lipid recovery ${ }^{21,25,26}$. Later obtained lipids were freeze-dried, and the total lipids in each algal strain obtained using the co-solvent system were determined gravimetrically, and the lipid content of each algal strain was expressed as a percentage of DW, respectively. The lipid productivity of each strain was calculated using Eq. $3^{10,14,26}$.

$$
\text { Lipid productivity }\left(m g L^{-1} d^{-1}\right)=\text { Biomass productivity } \times \frac{\text { Lipid content }}{100}
$$

FAME characterization. Typically, not all kinds of lipids in algae cannot be converted to fatty acid methyl esters (FAME), for example, glycolipids and phospholipids. Hence, the conversion of algal lipids to FAME and characterization of the obtained FAME is relevant to measure the content of lipids that are convertible to FAMEs ${ }^{10,30}$. The base-catalyzed transesterification of lipids was performed using $2 \mathrm{M}$ potassium hydroxide (KOH) in analytical grade methanol. The supernatant was collected when the phase separation of the samples was attained. The obtained supernatant was subjected to gas chromatography with mass spectrometry (GC-MS) analysis. During the investigation of ester, FAME mix C4-C24 and pentadecanoic acid methyl ester (Sigma-Aldrich) were used as a quantitative standard and as an internal standard respectively ${ }^{32-34}$. The obtained FAME was analyzed by Agilent GC-MS (GC6890N, MS 5975) with DB-wax FAME column $(30 \mathrm{~m}, 0.25 \mathrm{~mm}, 0.25 \mu \mathrm{m})$. The inlet temperature was $250^{\circ} \mathrm{C}$ in split mode. The oven temperature was programmed at $50^{\circ} \mathrm{C}$ for $1 \mathrm{~min}$, and it raised at the rate of $25^{\circ} \mathrm{C} /$ $\min$ to $200^{\circ} \mathrm{C}$ and $3^{\circ} \mathrm{C} / \mathrm{min}$ to $230^{\circ} \mathrm{C}$ and it was held there for $23 \mathrm{~min}$. The FAME composition was recognized and quantified using the National Institute of Standards and Technology (NIST) 2014 MS library and GCMS chromatogram ${ }^{29,35}$. The properties of algal FAME such as Iodine value (IV), saponification value (SV), and cetane number $(\mathrm{CN})$ were determined using empirical formulas given below ${ }^{36-39}$.

$$
\text { Cetane number }(C N)=46.3+\frac{5458}{S V}-0.225 \times I V
$$

Where saponification value (SV) are denoted in $\mathrm{mg} \mathrm{KOH} \mathrm{g}^{-1}$ and iodine value (IV) is presented in $\mathrm{g} \mathrm{I} 100 \mathrm{~g}^{-1}$.

The Eqs. 5 and 6, represent the empirical formula for the calculation of iodine value and saponification value of algal FAME respectively ${ }^{37-39}$.

$$
\begin{aligned}
& I V=\Sigma \frac{254 \times F \times D}{M W} \\
& S V=\Sigma \frac{560 \times F \times D}{M W}
\end{aligned}
$$

where, $\mathrm{F}$ is the percentage weight of each fatty acid, $\mathrm{D}$ is the total number of double bonds and MW is the molecular weight of the respective fatty acid.

All the experiments were performed in triplicates and average values were reported. The obtained triplicate results were performed with EXCEL (Microsoft Office Enterprise, 2016) and analysis of variance (ANOVA) for presented data was determined using MATLAB R2017a version. 


\begin{tabular}{|l|l|l|}
\hline Parameters & Units & Concentration \\
\hline $\mathrm{pH}$ & - & 5.5 \\
\hline $\mathrm{COD}$ & $\mathrm{mgL}^{-1}$ & 250 \\
\hline $\mathrm{TN}$ & $\mathrm{mgL}^{-1}$ & 8200 \\
\hline $\mathrm{NH}_{4}-\mathrm{N}$ & $\mathrm{mgL}^{-1}$ & 4300 \\
\hline $\mathrm{NO}_{3}-\mathrm{N}$ & $\mathrm{mgL}^{-1}$ & 3900 \\
\hline $\mathrm{TP}$ & $\mathrm{mgL}^{-1}$ & 200 \\
\hline $\mathrm{K}$ & $\mathrm{mgL}^{-1}$ & 500 \\
\hline
\end{tabular}

Table 1. The characterization of fertilizer plant wastewater.

2.5

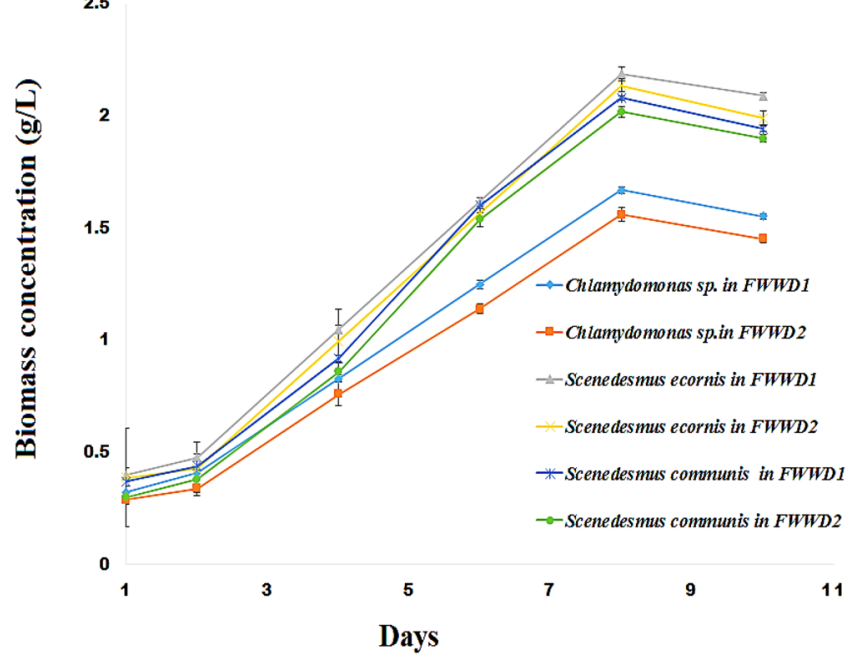

Figure 1. Growth curves of Chlamydomonas sp., S. communis, and S. erconis in FWWD1 and FWWD2 of pH 7.5 at $25^{\circ} \mathrm{C}$ with a continuous PFD of $150 \mu \mathrm{mol} \mathrm{m}^{-2} \mathrm{~s}^{-1}(\mathrm{mean} \pm \mathrm{SD})$.

\section{Results and Discussion}

Wastewater characterization. The characteristic features of fertilizer plant wastewater (FWW) are shown in Table 1. The total phosphorus (TP), chemical oxygen demand (COD), total nitrogen (TN), and pH of wastewater samples were monitored before algal cultivation. The collected wastewater had $8200 \mathrm{mgL}^{-1}$ of TN and 200 $\mathrm{mgL}^{-1} \mathrm{TP}$ and $\mathrm{pH}$ of 5.5. The COD level of undiluted wastewater sample was $250 \mathrm{mgL}^{-1}$.

Algal growth and biomass production. The growth behavior of Chlamydomonas sp., S. ecornis, and S. communis in FWWD1, and FWWD2 were described in (Fig. 1). Each curve represents the growth phase of each algal species in wastewater samples. The algal species showed a lag phase of two days in fertilizer plant wastewater. The algal species showed higher biomass concentration in FWWD1 compared FWDD2 due to the high amount of nutrients ${ }^{14,40}$. Subsequently, the algal growth entered to an exponential phase after day two where, Chlamydomonas sp., S. communis, and S. ecornis exhibited a significant rise in biomass production up to day eight. The Chlamydomonas sp., S. ecornis, and S. communis showed maximum biomass concentration of $1.66 \pm 0.028 \mathrm{gL}^{-1}, 2.19 \pm 0.012 \mathrm{gL}^{-1}, 2.08 \pm 0.017 \mathrm{gL}^{-1}$ in FWWD1 whereas $1.56 \pm 0.014 \mathrm{gL}^{-1}, 2.14 \pm 0.032 \mathrm{gL}^{-1}$, $2.02 \pm 0.011 \mathrm{gL}^{-1}$ in FWWD2 respectively. The growth behavior of each alga might be due to the effect of COD, nitrogen, and phosphorus concentration on each algal species ${ }^{6,14,40,41}$. The nutrients such as $\mathrm{N}$, P, and K contribute major percentage of algal biomass ${ }^{42,43}$ and it was higher in FWWD1 (100 fold diluted wastewater) than in FWWD2 (200 fold diluted wastewater). Moreover, the lower carbon source $\left(\mathrm{NaHCO}_{3}\right)$ to $\mathrm{TN}$ ratio due to high amount of TN in FWWD1 and high NPK amount in FWWD1 favored biomass production. The ANOVA analysis of variance of biomass concentration results showed a p-value lower than 0.05 is enough to conclude that biomass concentrations are significantly different for dilutions such as FWWD1, FWWD2 for different algal species.

The effect of $\mathrm{pH}$ on algal biomass production, biomass productivity in $\mathrm{FWWD} 1$, and FWWD2 at $25^{\circ} \mathrm{C}$ with a continuous PFD of $150 \mu \mathrm{molm}^{-2} \mathrm{~s}^{-1}$ is depicted in Fig. 2. The biomass concentration is depended on the $\mathrm{pH}$ of the culture medium because it influences the efficiency of nutrient absorption and photosynthesis of the algal species. Besides, the $\mathrm{pH}$ range 6-8 is suitable for algal cultivation, whereas low $\mathrm{pH}$ causes enzyme inhibition in photosynthesis process ${ }^{44-47}$. Chlamydomonas $\mathrm{sp}$. showed maximum biomass concentration and biomass productivity at $\mathrm{pH} 7.5$ whereas $S$. ecornis, and S. communis had maxima at $\mathrm{pH} 8.5$ in FWWD1, and FWWD2 illustrated in Fig. 2a,b ${ }^{44-46}$. All algal species showed maximum biomass concentration and productivity in FWWD1 samples. The biomass productivity of $209 \pm 2.68 \mathrm{mgL}^{-1} \mathrm{~d}^{-1}$ and $195 \pm 2.29 \mathrm{mgL}^{-1} \mathrm{~d}^{-1}$ were displayed by Chlamydomonas sp. in FWWD1, and FWWD2 correspondingly. S. ecornis showed a maximum biomass concentration and productivity of $2.70 \pm 0.071 \mathrm{mgL}^{-1}$ and $334 \pm 1.84 \mathrm{mgL}^{-1} \mathrm{~d}^{-1}$ in FWWD1 while $S$. communis exhibited $2.60 \pm 0.044$ 

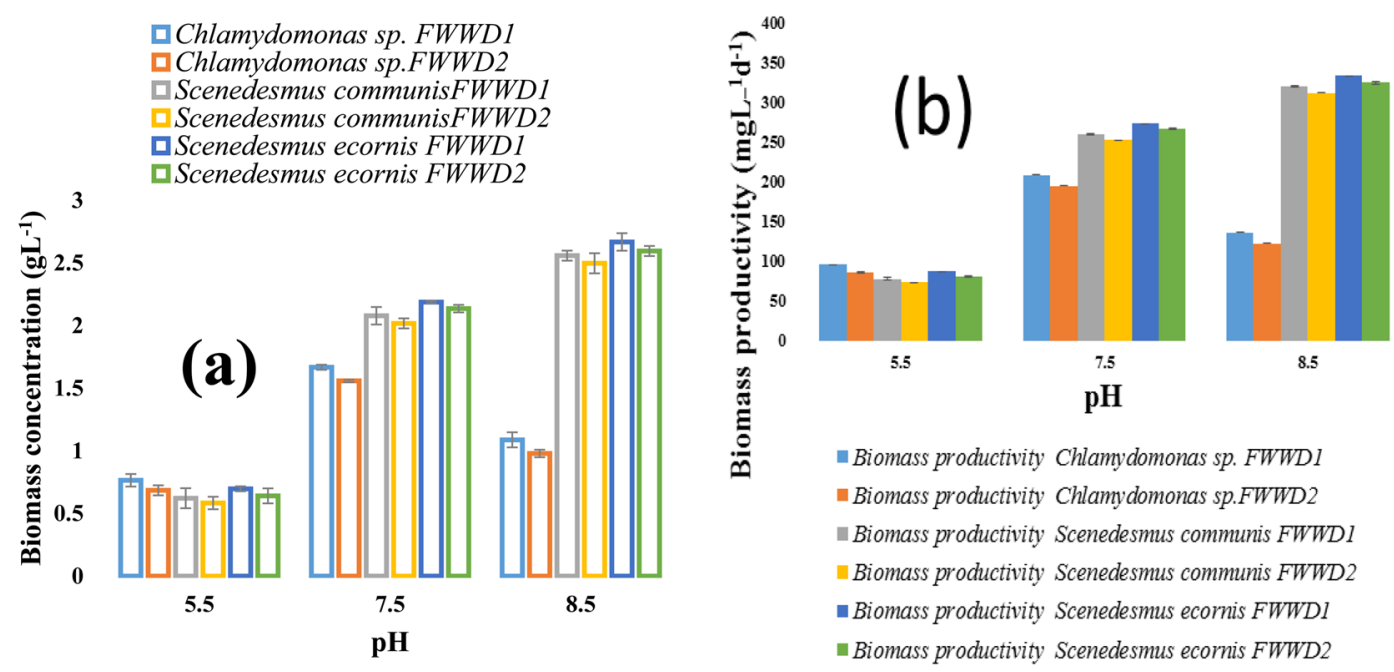

Figure 2. Effect of $\mathrm{pH}$ on (a) algal biomass production, and (b) biomass productivity in FWWD1 and FWWD2 at $25^{\circ} \mathrm{C}$ with a continuous PFD of $150 \mu \mathrm{mol} \mathrm{m}^{-2} \mathrm{~s}^{-1}$ (mean $\pm \mathrm{SD}$ ).
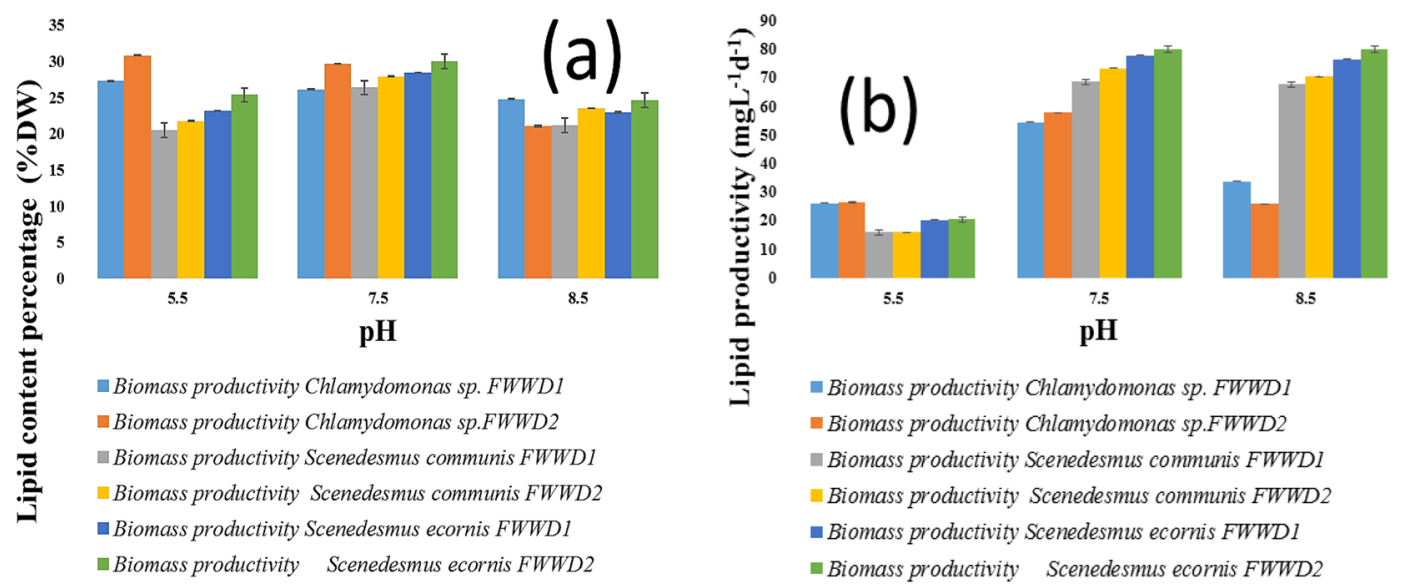

Figure 3. (a,b) Lipid content and productivity of different algal strains after co-solvent extraction (mean \pm SD).

$\mathrm{mgL}^{-1}$ and $320 \pm 1.25 \mathrm{mgL}^{-1} \mathrm{~d}^{-1}$ of biomass concentration and productivity in FWWD1 respectively. S. ecornis and $S$. communis showed biomass productivity of $313 \pm 2.0 \mathrm{mgL}^{-1} \mathrm{~d}^{-1}$ and $325 \pm 1.42 \mathrm{mgL}^{-1} \mathrm{~d}^{-1}$ in FWWD2 correspondingly. The results also indicated that there were significant $(\mathrm{P}<0.05)$ differences between the dilutions (FWWD1 and FWWD2) and pH used for cultivation for different algal species.

Lipid content and productivity. The maximum lipid content of $30.9 \pm 0.085 \%$ was observed in Chlamydomonas sp. at pH 5.5 followed by S. ecornis $(30.0 \pm 0.062 \%)$ and S. communis $(27.9 \pm 0.034 \%)$ at $\mathrm{pH} 7.5$ in FWWD2 (Fig. 3a). All algal strains exhibited maximum lipid content and productivity in FWWD2. Generally, under stressed conditions such as $\mathrm{pH}$, nutrient (nitrogen or phosphorus), starvation leads to the accumulation of lipids in microalgae. Under normal growth conditions, the microalgae use the ATP and NADPH are produced during photosynthesis for biomass concentration. As a result, $\mathrm{ADP}$ and $\mathrm{NADP}^{+}$are accessible as the electron acceptor for photosynthesis. During nutrients limited conditions lead to depletion of $\mathrm{NADP}^{+}$due to reduced cell growth and proliferation. The photosynthesis process is regulated by the abundance of light; therefore, it cannot be switch off completely. At this stage, fatty acid biosynthesis or triglycerides production act as a cell protective mechanism $\mathrm{NADP}^{+}$by the consumption $\mathrm{NADPH}^{48-50}$. The channelization of carbohydrates from the growth phase to TGA production was also possible during limited nutrient conditions ${ }^{51}$. The TGA production and accumulation can be enhanced by alteration in $\mathrm{pH}$, and it due to the adaptive mechanism of algae towards the $\mathrm{pH}$ of culture medium. Based on previously reported studies, Chlamydomonas sp. showed maximum lipid production under acidic conditions, whereas Scenedesmus sp. under slightly alkaline conditions due to their morphological difference ${ }^{45,46,48}$. The maximum content of lipids in algal species grown in FWWD2 is possibly due to the lower amount of nutrients and higher carbon source $\left(\mathrm{NaHCO}_{3}\right)$ to TN ratio compared to FWWD1 depicted in Fig. $3 \mathrm{a}^{6,41,52,53}$. Moreover, the smaller amount of nitrogen in FWWD2 in comparison to FWWD1 could have enhanced the lipid content ${ }^{40,48,53}$. The maximum lipid productivity by all algal strains was observed at pH7.5. Chlamydomonas sp., S. ecornis, and S. communis showed maximum lipid productivity of $57.8 \pm 1.87 \mathrm{mgL}^{-1} \mathrm{~d}^{-1}$, 


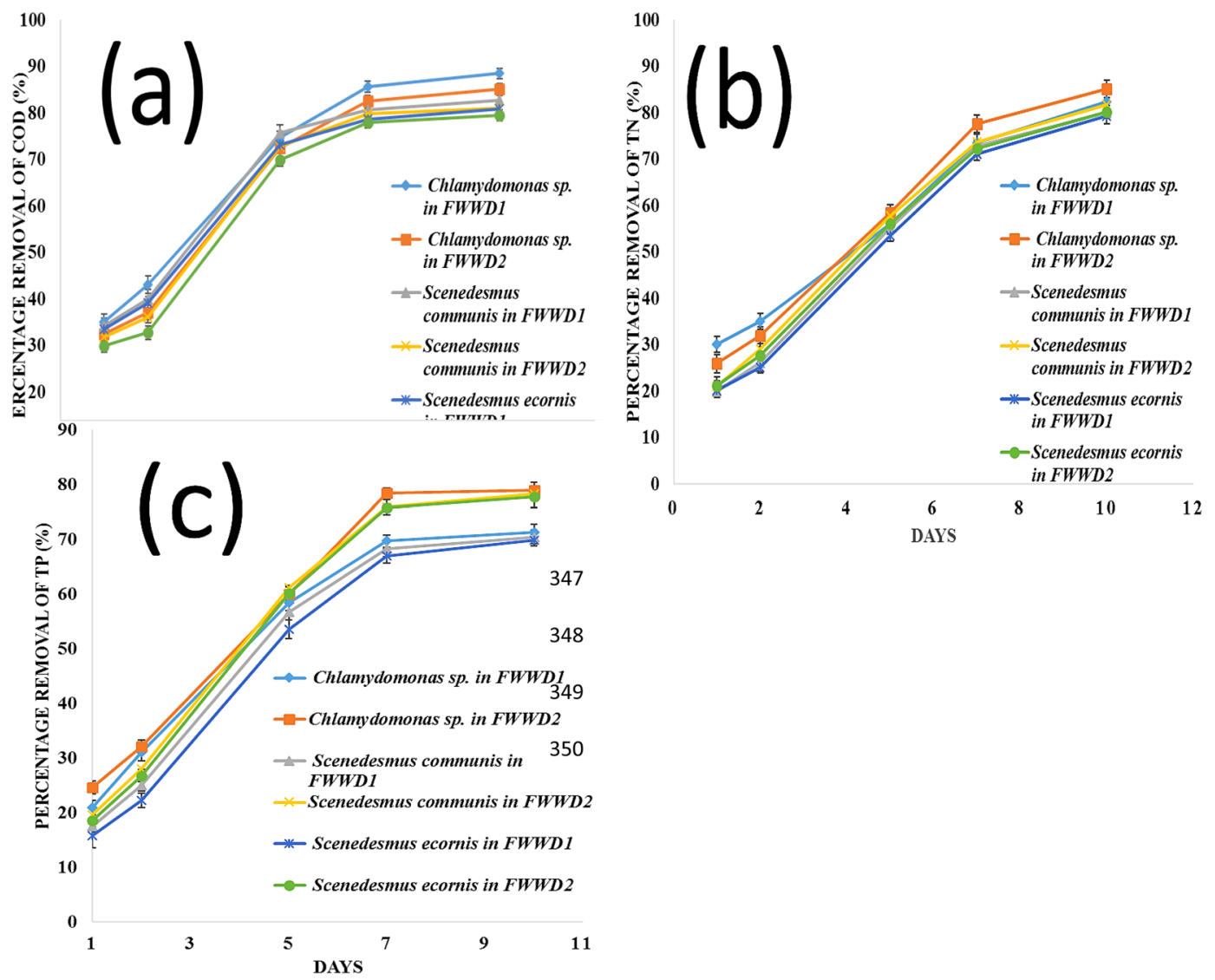

Figure 4. The fertilizer plant wastewater treatment performance by Chlamydomonas sp., S. ecornis, and S. communis at $25^{\circ} \mathrm{C}$ with a continuous PFD of $150 \mu \mathrm{mol} \mathrm{m}^{-2} \mathrm{~s}^{-1}$ at $\mathrm{pH} 7.5$ as percentage removal of (a) COD (b) $\mathrm{TN}$ and $(\mathbf{c}) \mathrm{TP}($ mean $\pm \mathrm{SD})$.

$80 \pm 2.04 \mathrm{mgL}^{-1} \mathrm{~d}^{-1}$, and $73.5 \pm 1.66 \mathrm{mgL}^{-1} \mathrm{~d}^{-1}$, respectively illustrated in Fig. 3b. The p-values obtained after ANOVA analysis of variance are smaller than 0.05 for mean results of lipid content and lipid productivity shows that obtained results were indicated significant differences in different dilutions (FWWD1 and FWWD2) for different algal species.

Nutrient removal. The previous studies show that treatment of various kinds of wastewater was possible using algal species ${ }^{6,52,54}$. The COD, N, and P removal mainly observed due to the consumption of microalgal cells during the growth process. Generally, algal cells adsorb inorganic nitrogen in the form of nitrate after the nitrification process or continue to be degraded into gas nitrogen ${ }^{55,56}$. The TP removal can be achieved by adsorption, ion exchange, or precipitation. The microalgae can degrade phosphate to some extent via microbial activities and besides microalgae, the accumulation of precipitated phosphorus during algal cultivation with a rise in $\mathrm{pH}^{57,58}$.

The current work indicates a drastic removal of COD in early days of algal cultivation (Fig. 4a). Chlamydomonas sp., S. communis, and S. ecornis exhibited higher removal of COD in FWWD1. The more significant removal of COD in FWWD1 than in FWWD2 is possibly due to the lower carbon source $\left(\mathrm{NaHCO}_{3}\right)$ to $\mathrm{TN}$ ratio due to high amount of TN in FWWD $1^{41,59}$. The maximum percentage of COD removal by Chlamydomonas sp, S. communis, and S. ecornis were $88.6 \pm 1.1 \%, 82.7 \pm 1.4 \%$, and $80.9 \pm 1.6 \%$ respectively within ten days (Fig. 4a).

The maximum percentage removal of TN in FWWD2 by Chlamydomonas sp, S. communis, and S. ecornis were $85.2 \pm 1.6 \%, 81.8 \pm 1.3 \%$, and $80.2 \pm 2.04 \%$ correspondingly (Fig. 4 b). Chlamydomonas sp, S. communis, and S. ecornis showed $82.5 \pm 2.02 \%, 80 \pm 1.7 \%$, and $79.3 \pm 1.3 \%$ removal of TN in FWWD1, respectively within ten days represented in Fig. 4b. All the algal strains showed maximum removal of TN in FWWD2. The maximum percentage removal of TN in FWWD2 is possibly due to the lower concentration of nitrogen in FWWD2 compared FWWD1 $1^{41,59,60}$.

Within ten days of cultivation, Chlamydomonas sp, S. communis, and S. ecornis in FWWD2 showed $79 \pm 1.3 \%$, $78.3 \pm 1.1 \%$, and $77.8 \pm 1.6 \%$ removal of TP respectively (Fig. $4 \mathrm{c}$ ). The TP removal was $71.4 \pm 1.4 \%, 70.5 \pm 1.9 \%$, and $69.9 \pm 1.2 \%$ by Chlamydomonas sp, S. communis, and S. ecornis in FWWD1 correspondingly shown in Fig. 4c. The TP removal was higher in wastewater samples with a low concentration of nutrients ${ }^{10,60}$. The smaller amount of nutrients might be the reason for increased removal percentage of TP in FWWD2 related to FWWD1. The COD, TN and TP removals within 10 days were significantly $(\mathrm{P}<0.05)$ different among different algal species for different dilutions (FWWD1 and FWWD2). 


\begin{tabular}{|c|c|c|c|c|c|c|c|c|c|}
\hline \multirow[b]{2}{*}{ FAME Composition } & \multicolumn{3}{|c|}{ Chlamydomonas sp. } & \multicolumn{3}{|c|}{ S. ecornis } & \multicolumn{3}{|c|}{ S. communis } \\
\hline & MWC & FWWD1 & FWWD2 & MWC & FWWD1 & FWWD2 & MWC & FWWD1 & FWWD2 \\
\hline \multicolumn{10}{|c|}{ Saturated fatty acids (\% of total FAME) } \\
\hline C16:0 & 24.37 & 30.51 & 33.44 & 33.05 & 37.45 & 38.56 & 20.4 & 23.12 & 25.51 \\
\hline C18:0 & 5.16 & 4.4 & 3.2 & 4.1 & 4.5 & 3.5 & 3.29 & 4.50 & 3.40 \\
\hline \multicolumn{10}{|c|}{ Unsaturated fatty acids (\% of total FAME) } \\
\hline C 16:1 & 1.35 & 1.29 & 2.59 & 1.05 & 1.55 & 1.79 & 1.28 & 1.15 & 2.59 \\
\hline $\mathrm{C} 18: \ln 9 \mathrm{c}$ & 8.75 & 9.27 & 22.60 & 34.98 & 33.59 & 38.24 & 21.09 & 19.88 & 23.69 \\
\hline $\mathrm{C} 18 \mathrm{2} 2 \mathrm{n} 6 \mathrm{c}$ & 20.86 & 19.30 & 18.98 & 2.36 & 3.44 & 2.51 & 6.55 & 5.16 & 5.57 \\
\hline $\mathrm{C} 18: 3 \mathrm{n} 3$ & 16.17 & 17.24 & 6.43 & 14.55 & 12.09 & 10.67 & 15.75 & 14.2 & 13.95 \\
\hline Total FAME (\%DW) & 8.89 & 10.05 & 15.99 & 8.83 & 9.88 & 10.46 & 6.6 & 7.07 & 8.95 \\
\hline Iodine value ( $\left.\mathrm{g} \mathrm{I} 100 \mathrm{~g}^{-1}\right)$ & 91.24 & 91.75 & 74.87 & 76.58 & 71.06 & 69.91 & 75.20 & 67.22 & 72.14 \\
\hline Cetane number & 60.15 & 57.81 & 59.66 & 58.43 & 58.76 & 58.23 & 68.25 & 70.12 & 65.45 \\
\hline
\end{tabular}

Table 2. Of FAME composition and properties of different algae in MWC, FWWD1, and FWWD2 within ten days.

Composition and properties of FAME. The FAME profile of Chlamydomonas sp., S. ecornis, and S. communis mainly consisted of saturated fatty acid methyl ester such as palmitic acid methyl ester (C16:0), stearic acid methyl ester (C18:0) and unsaturated fatty acid methyl ester like palmitoleic acid methyl ester (C16:1), oleic acid methyl ester (C18:1n9c), linoleic acid methyl ester (C18:2n6c), and $\alpha$-linolenic acid methyl ester (C18:3n3) (Table 2). The FAME yields $16 \%, 10.5 \%$, and $8.9 \%$ of DW were correspondingly attained by Chlamydomonas sp., S. ecornis and S. communis grown in FWWD2 at their optimum $\mathrm{pH}$. The proportion of saturated fatty acid (\% DW) was higher in fertilizer plant wastewater than in MWC medium. The increased saturated fatty acid content in Chlamydomonas sp. was observed in weakly acidic conditions whereas for Scenedesmus sp more significant amount of saturated fatty acid in slightly alkaline conditions of the wastewater samples ${ }^{53,61}$. Furthermore, the algae showed the rise in the amount of triglycerides (TGA), the increase in the concentration of oleic fatty acid and reduction in linolenic fatty acid amount in FWWD2, which was due to the lower level of nitrogen and phosphorus in the medium ${ }^{34,53}$.

The lower amount of unsaturated fatty acid or drop in linolenic fatty acid in algal species grown in fertilizer wastewater plant increases oxidation stability ${ }^{3,53,62}$. The lesser amount of long chain fatty acid reduces filter clogging at the lower temperature ${ }^{3,63,64}$. The increase in unsaturated fatty acid content reduces the pour point of fuel (Zhu et al., 2013). The calculated iodine value and cetane number of all algal FAME were within EN 14214 limits ${ }^{3,38}$.

\section{Conclusions}

The treatment of fertilizer plant wastewater was excellently performed by Chlamydomonas sp., S. ecornis, and S. communis. The biomass concentration, lipid content, and FAME composition depends on the $\mathrm{pH}$ and level of nutrients. In comparison with Chlamydomonas sp., the biomass concentration of S. communis and S. erconis were higher at alkaline $\mathrm{pH}$. Moreover, the biomass concentration and productivity of algae were maximum in wastewater samples with an increased level of nutrients. Chlamydomonas sp. showed the most significant lipid production at pH5.5 whereas S. communis and S. erconis at pH 7.5. Chlamydomonas sp., S. communis, and S. ecornis showed maximum removal of COD in wastewater samples with the highest concentration of nutrients while TN and TP removal were most significant in wastewater samples with the lower level of nutrients. All algaeshowed maximum total FAME (\%DW) in wastewater samples with the smallest amount of nutrients. The entire FAME (\%DW) was highest in the following order (a) Chlamydomonas sp., (b) S. erconis, and (c) S. communis. The fuel properties of the obtained algal FAME are suitable for proper fuel. The results of the current work showed a collaborative growth of microalgae in fertilizer wastewater and cost-effective production biodiesel from the obtained algal biomass. Thereby this approach offers a sustainable solution for energy production, wastewater treatment, and nutrient recovery.

Received: 3 November 2019; Accepted: 28 November 2019;

Published online: 13 December 2019

\section{References}

1. Ambat, I. et al. Application of Potassium Ion Impregnated Titanium Dioxide as Nanocatalyst for Transesterification of Linseed Oil. Energy \& Fuels 32, 11645-11655 (2018).

2. Gouveia, L. et al. Microalgae biomass production using wastewater: Treatment and costs. Scale-up considerations. Algal Res. 16, $167-176(2016)$

3. Ambat, I., Srivastava, V. \& Sillanpää, M. Recent advancement in biodiesel production methodologies using various feedstock: A review. Renew. Sustain. Energy Rev. 90, 356-369 (2018).

4. Ambat, I. et al. Dual application of divalent ion anchored catalyst: biodiesel synthesis and photocatalytic degradation of carbamazepine. Catal. green Chem. Eng. 2, 25-42 (2019).

5. Ambat, I. et al. Effect of lithium ions on the catalytic efficiency of calcium oxide as a nanocatalyst for the transesterification of lard oil. Sustain. Energy Fuels 3, 2464-2474 (2019).

6. Ambat, I., Tang, W. \& Sillanpää, M. Statistical analysis of sustainable production of algal biomass from wastewater treatment process. Biomass and Bioenergy 120, 471-478 (2019). 
7. Renato, J. et al. Applied Catalysis A: General Strontium zirconate heterogeneous catalyst for biodiesel production: Synthesis, characterization and catalytic activity evaluation. Applied Catal. A, Gen. 445-446, 76-82 (2012).

8. Dahiaya, A. Bioenergy - 1st Edition. In Bioenergy: biomass to biofuels (ed. Dahiaya, A.) (Elsevier Inc, 2015).

9. Lópeza, C. V. G. et al. Medium recycling for Nannochloropsis gaditana cultures for aquaculture_Elsevier Enhanced Reader.pdf. Bioresour. Technol. 129, 430-438 (2013).

10. Zhu, L. et al. Nutrient removal and biodiesel production by integration of freshwater algae cultivation with piggery wastewater treatment. Water Res. 47, 4294-4302 (2013).

11. Michels, M. H. A., Vaskoska, M. \& Al, V. M. Het Growth of Tetraselmis suecica in a tubular photobioreactor on wastewater from a fish farm _ Elsevier Enhanced Reader.pdf. Water Res. 65, 290-296 (2014).

12. Ansari, F. A. et al. Microalgal cultivation using aquaculture wastewater_Integrated biomass generation and nutrient remediation Elsevier Enhanced Reader.pdf. Algal Res. 21, 169-177 (2017).

13. Gao, F. et al. Continuous microalgae cultivation in aquaculture wastewater by a membrane photobioreactor for biomass production and nutrients removal. Ecol. Eng. 92, 55-61 (2016).

14. Guldhe, A. et al. Heterotrophic cultivation of microalgae using aquaculture wastewater_A biorefinery concept for biomass production and nutrient remediation _Elsevier Enhanced Reader.pdf. Ecol. Eng. 99, 47-53 (2017).

15. Ravindran, B. et al. Algal Biofuels. In Algal biofuels (eds. Gupta, S. K., Malik, A. \& Bux, F.) 1-38 (Springer International Publishing, 2017).

16. Patil, P. D., Reddy, H., Muppaneni, T., Mannarswamy, A. \& Schuab, T. Power dissipation in microwave-enhanced in situ transesterification of algal biomass to biodiesel. Green Chem. 14, 809-818 (2012).

17. Galadima, A. \& Muraza, O. Biodiesel production from algae by using heterogeneous catalysts: A critical review. Energy 78, 72-83 (2014).

18. Zhou, W. et al. Local bioprospecting for high-lipid producing microalgal strains to be grown on concentrated municipal wastewater for biofuel production. Bioresour. Technol. 102, 6909-6919 (2011).

19. Guo, Z. et al. Microalgae cultivation using an aquaculture wastewater as growth medium for biomass and biofuel production. J. Environ. Sci. 25, 85-88 (2013).

20. Kothari, R., Pathak, V. V., Kumar, V. \& Singh, D. P. Experimental study for growth potential of unicellular alga Chlorella pyrenoidosa on dairy waste water: An integrated approach for treatment and biofuel production. Bioresour. Technol. 116, 466-470 (2012).

21. Choi, S. A. et al. Effects of ionic liquid mixtures on lipid extraction from Chlorella vulgaris. Renew. Energy 65, 169-174 (2014).

22. Flamos, A., Georgallis, P. G. \& Psarras, J. Bioenergy options in the industrialized and developing world and opportunities for the clean development mechanism. Int. J. Green Energy 7, 647-661 (2010).

23. Hwang, J., Lee, S. \& Lee, W. H. Use of Microalgae for Advanced Wastewater Treatment and Sustainable Bioenergy Generation. Environ. Eng. Sci. 33, 1-16 (2016).

24. Kumar, R. R., Rao, P. H. \& Arumugam, M. Lipid extraction methods from microalgae: a comprehensive review. Front. Energy Res. 2, $1-9(2015)$.

25. Young, G. et al. Lipid extraction from biomass using co-solvent mixtures of ionic liquids and polar covalent molecules. Sep. Purif. 72, 118-121 (2010).

26. Kim, Y.-H. et al. Ionic liquid-mediated extraction of lipids from algal biomass. Bioresour. Technol. 109, 312-315 (2012).

27. Roy, S. S. \& Pal, R. Microalgae in Aquaculture: A Review with Special References to Nutritional Value and Fish Dietetics. Proc. Zool. Soc. 68, 1-8 (2015).

28. Standard methods for the examination of water and wastewater. (American Public Health Association (APHA), American Water Works Association (AWWA) and Water Environment Federation (WEF), Washington, D.C., USA., 2012).

29. Ambat, I. et al. Effect of different co-solvents on biodiesel production from various low-cost feedstocks using Sr-Al double oxides. Renew. Energy 146, 2158-2169 (2020).

30. Tossavainen, M. et al. Culturing of Selenastrum on diluted composting fluids; conversion of waste to valuable algal biomass in presence of bacteria. Bioresour. Technol. 238, 205-213 (2017).

31. Tossavainen, M. et al. Conversion of biowaste leachate to valuable biomass and lipids in mixed cultures of Euglena gracilis and chlorophytes. Algal Res. 35, 76-84 (2018).

32. Li, Y. et al. Characterization of a microalga Chlorella sp. well adapted to highly concentrated municipal wastewater for nutrient removal and biodiesel production. Bioresour. Technol. 102, 5138-5144 (2011).

33. Christie, W. W. Advances in lipid methodology. (The Oily Press, 1993).

34. Thoai, D. N., Photaworn, S., Kumar, A., Prasertsit, K. \& Tongurai, C. A novel chemical Method for Determining Ester Content in Biodiesel. Energy Procedia 138, 536-543 (2017).

35. Ho, S. et al. Optimizing biodiesel production in marine Chlamydomonas sp. JSC4 through metabolic profiling and an innovative salinity-gradient strategy. Biotechnol. Biofuels 7, 1-16 (2014).

36. Ambat, I. et al. Nano-magnetic potassium impregnated ceria as catalyst for the biodiesel production. Renew. Energy 139, 1428-1436 (2019).

37. Krisnangkura, K. A simple method for estimation of cetane index of vegetable oil methyl esters. J Am Oil Chem Soc 63, 552-553 (1986).

38. Kalayasiri, P., Jeyashoke, N. \& Krisnangkura, K. Survey of seed oils for use as diesel fuels. J. Am. Oil Chem.Soc. 73, 471-474 (1996).

39. Islam, M. A. et al. Microalgal Species Selection for Biodiesel Production Based on Fuel Properties Derived from Fatty Acid Profiles. Energies 6, 5676-5702 (2013).

40. Karpagam, R. et al. Enhancement of lipid production and fatty acid profiling in Chlamydomonas reinhardtii, CC1010 for biodiesel production. Ecotoxicol. Environ. Saf. 121, 253-257 (2015).

41. Yang, L. et al. Growth and lipid accumulation by different nutrients in the microalga Chlamydomonas reinhardtii. Biotechnol. Biofuels 11, 1-12 (2018)

42. Benemann, J. \& Oswald, W. Final Report to the US Department of Energy. Grant No. DEFG22-93PC93204, Pittsburgh Energy Technology Center, USA (1996).

43. Mata, T. M., Martins, A. A. \& Caetano, N. S. Microalgae for biodiesel production and other applications: A review. Renew. Sustain. Energy Rev. 14, 217-232 (2010).

44. Ma, C. et al. Molasses wastewater treatment and lipid production at low temperature conditions by a microalgal mutant Scenedesmus sp. Z-4. Biotechnol. Biofuels 10, 111 (2017).

45. Sun, H. et al. High - value biomass from microalgae production platforms: strategies and progress based on carbon metabolism and energy conversion. Biotechnol. Biofuels 11, 1-23 (2018).

46. Bakuei, N., Amini, G., Najafpour, G., Jahanshahi, M. \& Mohammadi, M. Optimal cultivation of Scenedesmus sp. microalgae in a bubble column photobioreactor. Indian J. Chem. Technol. 22, 20-25 (2015).

47. Zeng, X., Danquah, M. K., Chen, X. D. \& Lu, Y. Microalgae bioengineering: from CO2 fixation to biofuel production. Renew. Sustain. Energy Rev. 15, 3252-3260 (2011).

48. Sharma, K. K., Schuhmann, H. \& Schenk, P. M. High Lipid Induction in Microalgae for Biodiesel Production. Energies 5, 1532-1553 (2012).

49. Hu, Q. et al. Microalgal triacylglycerols as feedstocks for biofuel production: perspectives and advances. plant J. 54, 621-639 (2008).

50. Thompson G. A. Jr. Lipids and membrane function in green algae. Biochim. Biophys. Acta 1302, 17-45 (1996). 
51. Devi, M. P. \& Mohan, S. V. $\mathrm{CO}_{2}$ supplementation to domestic wastewater enhances microalgae lipid accumulation under mixotrophic microenvironment: Effect of sparging period and interval. Bioresour. Technol. 112, 116-123 (2012).

52. Gerloff-elias, A., Spijkerman, E. \& Pröschold, T. Effect of external pH on the growth, photosynthesis and photosynthetic electron transport of Chlamydomonas acidophila Negoro, isolated from an extremely acidic lake ( $\mathrm{pH}$ 2. 6). Plant, cell Environ. 28, 1218-1229 (2005).

53. Singh, S. P. \& Singh, P. Effect of temperature and light on the growth of algae species_ A review_Elsevier Enhanced Reader.pdf. Renew. Sustain. Energy Rev. 50, 431-444 (2015).

54. Shin, S. E. et al. Isolation, phenotypic characterization and genome wide analysis of a Chlamydomonas reinhardtii strain naturally modified under laboratory conditions: towards enhanced microalgal biomass and lipid production for biofuels. Biotechnol. Biofuels 1-15, https://doi.org/10.1186/s13068-017-1000-0 (2017).

55. Zhu, L., Li, Z. \& Ketola, T. Biomass accumulations and nutrient uptake of plants cultivated on artificial floating beds in China's rural area. Ecol. Eng. 37, 1460-1466 (2011).

56. Su, H., Zhang, Y., Zhang, C., Zhou, X. \& Li, J. Cultivation of Chlorella pyrenoidosa in soybean processing wastewater. Bioresour. Technol. 102, 9884-9890 (2011).

57. Ruiz-Marin, A., Mendoza-Espinosa, L. G. \& Stephenson, T. Growth and nutrient removal in free and immobilized green algae in batch and semicontinuous cultures treating real wastewater. Bioresour. Technol. 101, 58-64 (2010).

58. Kim, Y., Bae, B. \& Choung, Y. Optimization of biological phosphorus removal from contaminated sediments with phosphatesolubilizing microorganisms. J. Biosci. Bioeng. 99, 23-29 (2005).

59. Bhatt, N. C., Panwar, A., Bisht, T. S. \& Tamta, S. Coupling of algal biofuel production with wastewater. Sci. World J. 2014, (2014).

60. Kamyab, H. et al. Efficiency of Microalgae Chlamydomonas on the Removal of Pollutants from Palm Oil Mill Effluent (POME). Energy Procedia 75, 2400-2408 (2015).

61. Tao, G., Yaakob, Z. \& Sobri, M. Biomass production and nutrients removal by a newly-isolated microalgal strain Chlamydomonas sp in palm oil mill effluent (POME). Int. J. Hydrogen Energy 4888-4895, https://doi.org/10.1016/j.ijhydene.2015.12.010 (2016).

62. Ankita, J., Ceballos, R. M. \& Murthy, G. S. Effects of Environmental Factors and Nutrient Availability on the Biochemical Composition of Algae for Biofuels Production: A Review. Energies 6, 4607-4638 (2013).

63. Huo, S. et al. Cultivation of Chlorella zofingiensis in bench-scale outdoor ponds by regulation of $\mathrm{pH}$ using dairy wastewater in winter, South China. Bioresour. Technol. 121, 76-82 (2012).

64. P'erez, A. et al. Winterization of peanut biodiesel to improve the cold flow properties. Bioresour. Technol. 101, 7375-7381 (2010).

\section{Acknowledgements}

We would like to gratefully acknowledge Yara Suomi Oy, Siilinjärvi, ohjois-Savo, Finland for providing wastewater samples for research studies. We would like to acknowledge Mr. Manu Bose Ambat for providing guidance on MATLAB for statistical analysis.

\section{Author contributions}

Indu Ambat is the primary researcher who planned, performed experiments, collected all data except nutrient removal, analyzed all data, interpreted results, and wrote the first draft of the article. Sabina Bec collected data related to nutrient removal. Elina Peltomaa provided the algal strain for this work. The Elina Peltomaa, Varsha Srivastava Anne Ojala, and Mika Sillanpää helped in the final drafting of the article and critical revision of the manuscript. All the authors gave their final approval for the submitted article.

\section{Competing interests}

The authors declare no competing interests.

\section{Additional information}

Correspondence and requests for materials should be addressed to I.A.

Reprints and permissions information is available at www.nature.com/reprints.

Publisher's note Springer Nature remains neutral with regard to jurisdictional claims in published maps and institutional affiliations.

(c) (i) Open Access This article is licensed under a Creative Commons Attribution 4.0 International (c) License, which permits use, sharing, adaptation, distribution and reproduction in any medium or format, as long as you give appropriate credit to the original author(s) and the source, provide a link to the Creative Commons license, and indicate if changes were made. The images or other third party material in this article are included in the article's Creative Commons license, unless indicated otherwise in a credit line to the material. If material is not included in the article's Creative Commons license and your intended use is not permitted by statutory regulation or exceeds the permitted use, you will need to obtain permission directly from the copyright holder. To view a copy of this license, visit http://creativecommons.org/licenses/by/4.0/.

(C) The Author(s) 2019 